\begin{tabular}{|c|c|}
\hline $\begin{array}{c}\text { ASIAN SOCIAL WORK } \\
\text { JOURAL } \\
\text { (ASW) }\end{array}$ & Asian Social Work Journal (ASWJ) \\
& Volume 3, Issue 1, March 2018 \\
& e-ISSN : 0128-1577 \\
& Journal home page: \\
& www.msocialwork.com \\
\hline
\end{tabular}

\title{
Assesing Need for Training Postgraduate on Social Security in Vietnam
}

\author{
Nguyen Trung Hai ${ }^{1}$ \\ 1University of Labor and Social Affairs, Vietnam
}

Corrrespondence: Nguyen Trung Hai (hainguyentrung1979@gmail.com)

\begin{abstract}
This paper aims to assess the Need for Training Postgraduate on Social Security in Vietnam. Base on questionnaires from 400 to staff working in the field of social security and deep interviews of 30 people which are experts, lecturers in university, the result of this study has described a general picture about need of social security training. Specifically, findings show that: for the Strengths and Opportunities: First, the State always has the right policies on social security. Ensuring social security for every people is the consistent policy in Vietnam; Second, the social security units are increasingly being developed in terms of quantity and quality; Third, human resources in this area are enthusiastic, experience and qualified but just some of them have degree related to social security; Fourth there has been a great deal of interest from the State for improving the quality of human resources in supplementing their knowledge of Social Security through National programs and projects; Fifth, educational institutions have been paying more attention, spending more time and funds for the training and developing capacity of lecturers in social security; Sixth, numbers of educational institutions having social security subjects in their training curriculum have increased faster. Weakness and Threats: First, despite the attention of the Party and the State, Vietnam social security policy system is scattered, overlapped; Second, number of staff working in the social security sector is largely unskilled and unqualified in term of social security knowledge; Third, for educational institutions: there has been interest and investment in research, teaching and training in the social security industry but still limited; lecturers with a degree in Social Security are also very limited. Most of them switched from other specialization; most of the educational institutions do not have clear orientation to develop Social Security curriculum at postgraduate level; the syllabus for social security topics is not much. Many new curriculums are translated from foreign materials so some contents are not completely suitable with the situation of Vietnam; currently, there is no social security training code. Base on the SOWT, this paper has discussed and recommended solutions to develop social security training program at postgraduate level to meet the need of high quality human resources on social security in Vietnam.
\end{abstract}

Key words: social security, social work, social need, training curriculum

\section{Introduction}

Since the implementation of the Innovation Policy, moving to a Socialist-Oriented market economy, Vietnam's economy has always reached high growth. This achievement allows Vietnam to have more resources to implement and expand the Social Security policy system. Base on functions and tasks, many agencies are implementing Social Security activities, including the Ministry of Labor, Invalids and Social Affairs, the Committee for Ethnic Minorities and Mountainous Areas, the Ministry of Agriculture and Rural Development Rural development, Mass organizations, Socio-political 
Organizations, Training institutions, Research institutes, NGOs etc. This has led to the high need to employ well trained staff on Social Security. However, there is currently no educational institution in Vietnam having Social Security program. They just include some Social Security subjects in their curriculum such as Sociology, Social Work or Social Management program. This is considered to be the cause of the serious shortage of high quality human resources in social security which limits the capacity of building, planning and implementing social security policies; limit the provision welfare services for people at all levels from central to local. Many activities in the field of social security in Vietnam are now forced to use staff that have not been trained in social security or trained in many different sectors. According to statistic, there are about 50,000 staffs working in the area related social security. Many of them have degree different with social security and it effects to their performance in work place. One of solutions is to participate in short social security training course. However, for the systematic and theoretical knowledge to have high quality human resources, the best solution is to have social security program at postgraduate level.

Thus, the study of "Assessing Need for Training Postgraduate on Social Security in Vietnam" is very necessary. The result of this study describes a picture about need of social security training thus provides recommendations to develop social security postgraduate program to meet the need of high quality human resources in this area. The study was conducted by a team from the Department of Social Work at the University of Labor and Social Affairs based on the request of the Ministry of Labor, Invalids and Social Affairs.

\section{Objectives of study}

The study focuses on five specific objectives:

i. Describing the necessity of postgraduate training in Social Security;

ii. Assessing training needs on social security at the postgraduate level of the staff working in social security field;

iii. Drawing lessons for Vietnam about social security program through studying and examining the postgraduate training on social security in other countries;

iv. Assessing the status of postgraduate training on social security in some educational institutions in Vietnam;

v. Proposing training program on Social Security in Vietnam.

vi. Proposing some solutions for the implementation of postgraduate training in social security in Vietnam

\section{Research Methods}

\section{Research Subject}

Need for Training Postgraduate on Social Security in Vietnam

\section{Research Scope}

Research Content: The study focuses on training need for postgraduate on the area of Social Security.

Research Areas: Social Security educational institutions in Ho Chi Minh City and Hanoi; Stage organizations in the area of social security.

Research Time: 2010 - 2015.

Document analysis method: Synthesize and analyze the contents and training programs of universities which have specialized training in social security-related fields in Vietnam;

i. Synthesize, analyze the documents about experience of postgraduate training related to Social Security of some countries in the world; and 
ii. Synthesize and analyze the system of legal documents stipulating the postgraduate training of Vietnam.

Questionnaire survey method: 400 questionnaires were distributed to staff (officers and leaders working in the field of social security ...) to evaluate:

i. The current situation of human resources working in the area of social security (Number, kind of degree, experiences, performance difficulties in their current work...)

ii. The training needs about Social Security (training topics, training time and budget and other necessary need for training)

In-depth interview method: 30 people which are experts, lecturers in university, social security officers to evaluate and propose Social Security program for postgraduate.

Seminar method: 3 sessions of group discussion on social security content and training program, including experts, lecturers, social security officers and Students enrolled in training programs close to Social Security.

\section{Research findings}

\section{Strengths and Opportunities}

First, the State always has the right policies on social security. Ensuring social security for every people is the consistent policy in Vietnam. Strengthening and ensuring social security is the basic solution to have sustainable poverty reduction, improving people's living standards and contributing to the stabilization of social politics in Vietnam. Therefore, the Party and State have a lot of social security policies for people, mobilizing many resources to participate in ensuring social security. Recognizing this, over the past years, many social security units have been invested and developed.

Second, the social security units are increasingly being developed in terms of quantity and quality. Particularly, the Department of Labor, Invalids and Social Affairs have 320 social protection centers, treatment and care for 47,609 people who are invalids soldiers in the war, people having merit with country and vulnerable group such as orphans, lonely and helpless elderly people, mental health illness people, people with disability, HIV infected people, drug addicts... Thus staff in those centers do need various and profound knowledge on social security to deal with social issue at macro level such as Planning social policy and at micro level such as providing treatment for different clients.

Third, human resources in this area are enthusiastic, experience and qualified. However degrees are various in many different professions. There is just a small percentage of staff having qualified degree such as social work, sociology, psychology... (Only accounts for about 25.9\%). Thus the current trend should retrain for remaining staff about Social Security topics to improve work efficiency.

One thing should be considered that the proportion of staff having bachelor degrees is highest $(61.2 \%)$. With the high proportion of university graduates, there could be a great need in the future to participate in higher-level training courses to meet the increasing professional requirements in their work. Training and Education institutions should have well preparation to provide good training course about social security to meet the current need in this area.

Fourth, there has been a great deal of interest from the State for improving the quality of human resources in supplementing their knowledge of Social Security through National programs and projects. Based on national schemes such as Project $32^{1}$ and Project $1215^{2} \ldots$ staffs are being facilitated for capacity building through training courses. Typically, from 2011 to 2017 held:

\footnotetext{
${ }^{1}$ National project for development social work profession in the period of $2010-2020$

2 Scheme on Social Assistance and Rehabilitation for People with Mental Illness base on Community, period 2011-2020
} 
- $\quad$ Training on social work and social security under Project 32 for senior managers: About 500 trainees.

- $\quad$ Training for Social Welfare Managers in Mental Health Care under Project 1215: About 900 trainees

- In the coming time, the Social Protection Department will support localities to train about 1,000 targets for social work bachelors. This is a major effort in standardizing the professional qualifications of staff working in social security area.

In sort, with consideration of Vietnamese government, the human resources in social security sector have been built and developed over the years. It is operated in many different fields, contributed to implement good policies and ensured the stability of socio-economic development in the country.

Fifth, educational institutions have been paying more attention, spending more time and funds for the training and developing capacity of lecturers in social security. Perhaps, because of that, it contributes significantly to the lecturer's need to improve their professional knowledge and skills in this area. This is a good basis for educational institutions to be able to provide good social security training courses.

Sixth, numbers of educational institutions having social security subjects in their training curriculum have increased faster. According to the current rapid assessment, about 50 training institutions have been involved in social security training. Many specializations with close and related social security have been developed such as: Social work; Social insurance; Psychology... with the participation of many universities in the country such as: University of Labor and Social Affairs; Social sciences and humanities; Hanoi Teaching University; Trade University, Vinh university, Hue University... As a result, it timely provides qualified human resources working in social security area.

Institutions of higher education, recently, have paid attention and focused to develop social security subjects such as Introduction to Social Security, Social Relief, Social Incentives, Social Insurance, Social Work and special topics related to Social Security. Structure in Universities has started to form departments and divisions related to social security such as Social Work Departments, Divisions of Social Security, Department of Social Management.

The quality of lecturers is constantly improved and enhanced through training courses. In Vietnam, currently, there are about 7 educational institutions provide Masters and 2 educational institutions provide $\mathrm{Ph} . \mathrm{D}$ social work courses including social security subjects. Many lectures are also assigned to participate in training courses in abroad. The curriculum materials also have been taken into account. Educational institutions have developed their own teaching materials. Some of them use materials translated from abroad to teach. As their response, each educational institution yearly develops 4 or 5 books related to social security.

\section{Weakness and Threats}

First, despite the attention of the Party and the State, Vietnam social security policy system is scattered, overlapped, ineffective, job creation and poverty reduction still face with difficulties, nearpoor and poor households remain high; Low social support; Education and training have not met development requirements; The protection and care of people's health, especially for the poor, people in remote and ethnic minority areas are still limited; The rate of child malnutrition remains high and decreases slowly; The proportion of people participating in social insurance, health insurance is not high; The living standards of the poor and ethnic minorities have not yet reached the minimum level; There is a gap between the mountainous areas and the ethnic minorities comparing with the national average.

Second, number of staff working in the social security sector is largely unskilled and unqualified in term of social security knowledge. Some of them participating social security training courses, however, it is just a small number. There is still many unskilled staff lacking social security knowledge and skill. Specific training courses under the State programs are only directed to the provincial leaders. District and commune officials have almost no capacity building on social security. 
Training courses just provide basic knowledge and with short time, so the demand of staff for professional capacity building is still very high. The demand come from: Jobs require professionalism more and more so many employees have been facing certain difficulties in their work; Number of employees with a degree in social security is rare; Last but not least, at present, staff must have a degree appropriate with their job position

Third, for educational institutions, there has been interest and investment in research, teaching and training in the social security industry but still limited. There are about almost 50 educational institutions provide training program with social security subjects. However, there are only 2 or 3 social security subjects in their training curriculum. University having social security subject the most is University of Labor and Social Affairs, but, they just have only 4 subjects.

Lecturers with a degree in Social Security are also very limited (just 20 to 30 percent in average in each educational institution). Most of them switched from other specialization and they build their capacity through self-study materials or short-term training courses. Some teachers who study abroad have basic knowledge on social security, but they are limited in practical knowledge in Vietnam because they just pay much attention to theory. One of the main reasons is that Vietnam lacks a lot of practice facilities so it also affects to training quality.

Most of the educational institutions do not have clear orientation to develop Social Security curriculum at postgraduate level. (No university has established the Social Security Faculty.) It is because they want to focus on the social work at the Master and Doctoral level in order to implement the Government Project 32. However, with the high demand on training social security, educational institutions should seriously consider to set up and develop social security training curriculum in different levels.

The syllabus for social security topics is not much. Many new curriculums are translated from foreign materials so some contents are not completely suitable with the situation of Vietnam.

Currently, there is no social security training code. This is a very important legal barrier for universities to participate in high-level social security training.

\section{Discussion and Solutions}

Currently, the need for training in social security in social settings is enormous. The results show that there is a great need for training on social security in Vietnam both in terms of quantity and quality. Specifically, $87.4 \%$ have a need for post-graduate training in Social Security. Among them, 91.5\% wished to have master degree and $8.5 \%$ wished to be trained in doctoral degree. Of those, 31-45 years of age had the highest demand for post-graduate education in Social Security (89.8\%). Men have higher demand $(90.1 \%)$ in social security training than women $(78.3 \%)$.

Following job position and working year, it shows that the leadership/management group had a higher need for training $(90.4 \%$ vs. $85.7 \%)$. Groups with less than 1 year of work experience have higher training needs than other seniority groups $(94.9 \%)$. It is explained that senior staff is familiar with their work so they could complete their work by experience. For staff less than 1 year, they do need to be built capacity to work more effective so they often eager and ready to take training course.

However, as analyzed above, there are many weaknesses that impede the training of this field. The first is a policy issue. Although Vietnam has many programs and policies to support clients, even policy and programs focusing on education and training. However, there are no specific policies towards the development of Social Security at high level. This has affected on the training human resources specialized in Social Security. 


\section{Developing and completing Policies}

The local government office needs to studie and issue the code of Social Security

Need to have policies to support the program development of specialized Social Security

Extend international cooperation focusing on educational institutions in the field of social security.

Develop national and international programs/projects to mobilize resources to develop the Social

Security training program

Social institutions need specific policies to develop human resources on social security

Facilitate staff participation in the field of Social Security

Arrange and arrange appropriate work with trained staff in this field

\section{Developing resources for training on Social Security}

Society is currently in need of postgraduate training in social security (focus on staff working in the field of Labor, Invalids and Social Affairs). However, there are many reasons which educational institutions are facing, just prevent them to provide postgraduate social security courses. Main reasons are lacking of lecturer teaching in this field; Lacking of materials, books and; Lecturers are also not well qualified in social security...So, in order to have solutions for developing lecturers for Postgraduate Social Security training, it is necessary that these solutions be implemented in parallel with the mechanisms and policies as well as guidelines and specific directions of the Ministry of Labor, Invalids and Social Affairs as well as the Ministry of Education and Training. For the development of lecturer for social security training, we propose some solutions as follows:

\section{Developing lecturers having social security degree}

In Circular 38 of the Ministry of Education and Training 2010 on "Regulations on the conditions, dossiers, procedures permit training, suspension of enrollment, withdrawal of decisions permitting the training of disciplines or specialized subjects. Master's degree, doctoral degree ", Clause 3, Article 2 stipulates that educational institutions should have sufficient teaching teams in terms of quantity and quality to be allowed to provide postgraduate training, in particular:

i. Full time lecturers must have at least master's degree participates in teaching at least $70 \%$ of the training program. For basic knowledge and specialized knowledge, lecturers participating in theoretical teaching must have doctorate degrees;

ii. Having at least 5 full-time lecturers with doctoral degrees near with training majors, and from 5 full-time lecturers, at least having 3 persons of the same training majors.

However, according to the survey, most of the educational institutions do not have Ph.D in Social Security, only in Sociology, Psychology, Social Work or Social Development. Thus, according to the regulations in the Ministry of Education and Training's Circular 38, educational institutions need to urgently have strategy to develop lecturers having $\mathrm{PhD}$ degree in social security in the coming time.

The Ministries and agencies under the Ministry as well as educational institutions should actively plan to cooperate with foreign partners to prioritize the doctoral degree in social security. Also refer to the annual scholarship program of the Ministry of Education and Training. Every year under the 911 scheme, in 2014-2015, the Ministry of Education and Training usually offers scholarships for students to participate in graduate training courses abroad. In 2014-2015, the Ministry approved 1,200 overseas fellowships for 7 sectors, of which 150 were for social science holding $12.5 \%$.

Promote collaboration with foreign educational institutions to develop lecturers through research and exchanging lecturer activities. For sending and selecting lecturers to participate social security training courses in abroad, it could be based on the ranking of the prestigious institutions of social security training. As such, lecturers need to register for the exam and contact to those institutions to understand necessary procedures before applying for admission.

Lecturers should also actively participate or training institutions should also create conditions for lecturers to participate in short courses in the field of Social Security implemented by international and 
local organizations. Base on this situation, NGOs and Government departments should take in to the consideration to have training activities on social security in their annual programs.

\section{Development Social Security books and materials}

One of the recommended important solutions is to develop books and materials necessary for training and lecturing social security. Currently, although limited, but we have basic social security books needed for training for example Introduction of social security; Social Privilege: Social Policy; Social Assistance; Social Insurance... In the future, in order to develop social security at higher level like postgraduate social security program, educational institutions should focus on developing specialized curricula in social security such as Social Security with disadvantaged groups such as the elderly, children with disabilities, poor people. It also should base on the life-cycle approach to develop materials. Furthermore, to meet requirement for postgraduate program, research-oriented materials have to be concerned such as Research methods in social security. Last but not least, materials and books have to cover the area of social security at macro level such as Social Administration in social security, Social security project design, Planning and Analyzing policy.

\section{Resources to develop books and materials}

According to the annual plan, the training institutions are approved to develop the curriculum according to the internal budget. Therefore, training institutions need to have a strategy and plan to supplement the syllabus of social security.

Collaborate with domestic and international organizations to implement studies and researches in the field of social security. The research result will be excellent outcome to put into content of books and materials in social security.

Under Project 32, training institutions have now compiled curricular materials for staff in the community. However, the direction in the next phase of project 32 will focus on compiling university and postgraduate curricula. Therefore, it could take to concern that educational institutions should focus on the development of additional syllabus postgraduate majoring in Social Security. Thus we can take the advance of the resources in Project 32 in the developing social security materials.

\section{References}

Margaret S. Malone. Agenda for social security: challenges for the new congress and the new administration, 2011

Ministry of Labor, Invalids and Social Affairs. Scheme on some social policy issues, period 20122020

Ministry of Labor, Invalids and Social Affairs, Strategic Social Security Strategy period 2011-2020

National project for the development of professional work in the period $2010-2020$

National workshop. Practical and Integrative in social work development in Vietnam. Youth Publishing House, 2014

Nguyen Hai Huu. Introductory Syllabus for Social Security. Labor and Social Publishing House. Hanoi, 2012.

Nguyen Trung Hai and Pham Hong Trang. Report on Training Needs of Human Resources in Labor, Invalids and Social Affairs, Da Nang City, 2013.

Orientation for social security development period 2011-2020

Scheme on Social Assistance and Rehabilitation for People with Mental Illness base on Community, period 2011-2020

Tran Hau, Doan Minh Huan, Development of social services in our country until 2020 a number of theoretical and practical issues, National Political Publishing House, Hanoi, 2012;

$\mathrm{Vu}$ Van Phuc, Social Security in Vietnam towards 2020, National Political Publishing House, Hanoi, 2012 